- FINANSE I PRAWO FINANSOWE.

- Journal of Finance and Financial Law

Grudzień/December 2019 • vol. 4(24): 11-31

http://dx.doi.org/10.18778/2391-6478.4.24.02

\title{
KREDYT STUDENCKI JAKO ŹRÓDŁO FINANSOWANIA EDUKACJI WYŻSZEJ
}

\author{
Daria Cieślak \\ Wydział Ekonomiczno-Socjologiczny, Uniwersytet Łódzki
}

\begin{abstract}
Streszczenie
W Polsce kredyt studencki udzielany jest od 1998 roku. Jak się okazuje obecnie nie jest on dość popularny, a z roku na rok udzielanych kredytów studenckich jest coraz mniej. Powstaje pytanie dlaczego tak się dzieję i co na to wpływa? Celem niniejszego artykułu jest przedstawienie i ocena funkcjonowania kredytu studenckiego oraz wyjaśnienie sytuacji, dlaczego kilka lat temu udzielano ich kilkadziesiąt tysięcy, a w chwili obecnej (2019 r.) znacznie mniej. Przedstawiony zostanie także związek dobrej sytuacji finansowej z podjęciem decyzji o zaciągnięciu kredytu studenckiego.
\end{abstract}

Słowa kluczowe: preferencyjne kredyty studenckie, sytuacja finansowa studentów.

JEL Class: D14, G29, E51, 122. 


\section{WPROWADZENIE}

„Młodzi dorośli” to osoby mające 18-24 lat. Są przypadki, w których do tej grupy zaliczamy także osoby starsze, podejmujące studia III stopnia, bądź zaczynające następny kierunek. Są to jednostki dojrzałe pod względem biologicznym, jednak nie są w stanie utrzymywać się samodzielnie, uzależnione (całkowicie lub częściowo) od rodziców bądź opiekunów prawnych i liczące na ich wsparcie finansowe. Uczące się lub studiujące, rzadziej rezygnujące z edukacji i zaczynające swoją karierę zawodową. Są to osoby, które jeszcze nie podejmują samodzielnie ważnych decyzji życiowych [Maciejewski 2014: 158].

W Polsce kredyt studencki udzielany jest od 1998 roku. Jak się okazuje obecnie nie jest on jednak dość popularny, a z roku na rok udzielanych kredytów studenckich jest coraz mniej. Celem niniejszego artykułu jest przedstawienie i ocena funkcjonowania kredytu studenckiego oraz wyjaśnienie sytuacji, dlaczego kilka lat temu udzielano ich kilkadziesiąt tysięcy, a w chwili obecnej (2019 r.) znacznie mniej. Hipoteza badawcza, jaka przyjęto na potrzeby artykułu brzmi: kredyt studencki jest mało popularny wśród studentów w Polsce z powodu ich dobrej sytuacji finansowej.

\section{POLSKI STUDENT NA TLE STUDENTÓW Z EUROPY}

W Polsce od 1991 do 2006 roku liczba studentów ciągle wzrastała. W 2006 roku na polskich uczelniach było 1953832 studentów. To największa jak do tej pory liczba osób studiujących w naszym kraju w jednym roku. Po roku 2006 zanotowano, że coraz mniej młodych osób wybierało się na studia. W 2017 roku potwierdzono liczbę 1291900 studentów, a to aż o 661932 mniej niż w 2006 roku, a mniej o 113233 niż w roku poprzednim. Powodem takiego stanu rzeczy jest ciągle zmniejszająca się liczba osób w wieku 19-25 lat (w takim przedziale wiekowym najwięcej młodych osób decyduje się na studiowanie). Przyczyną także jest demografia, wyjeżdżanie młodych osób za granicę lub podejmowanie przez nich decyzji by skończyć edukację, usamodzielnić się i znaleźć sobie dobrze płatną pracę [RAPORT ZBP Portfel Studenta Edycja III, Październik 2018 r.]. Okazuje się, że w ostatnich latach różnica między wynagrodzeniem osób po szkole wyższej a pozostałymi znacznie spadła, co oznacza, że większa część młodych ludzi po maturze wybiera edukację pozaformalną, a nie studia [www1].

Dla osób, które studiują ważnym aspektem jest ich budżet. Źródłem ich dochodu jest wsparcie finansowe od rodziców, stypendium naukowe oraz socjalne, oszczędności, a także ich własne zarobione pieniądze. Najbogatszymi na tle młodych osób z innych krajów są studenci ze Szwajcarii, a także Islandii. W obu 
przypadkach miesięczny budżet przekracza 2100 euro. Porównując polskiego studenta do jego kolegów z tych dwóch krajów, widać ogromną różnicę. Jego przychód na miesiąc wynosi 471 euro, znacznie mniej od Szwajcarów i Islandczyków. Przeliczając na złotówki, miesięczny budżet studentów w Polsce to około 1900 zł. Dla porównania 2100 euro w przeliczeniu na złotówki to około 9000 zł [RAPORT ZBP Portfel Studenta Edycja III, Październik 2018 r.].

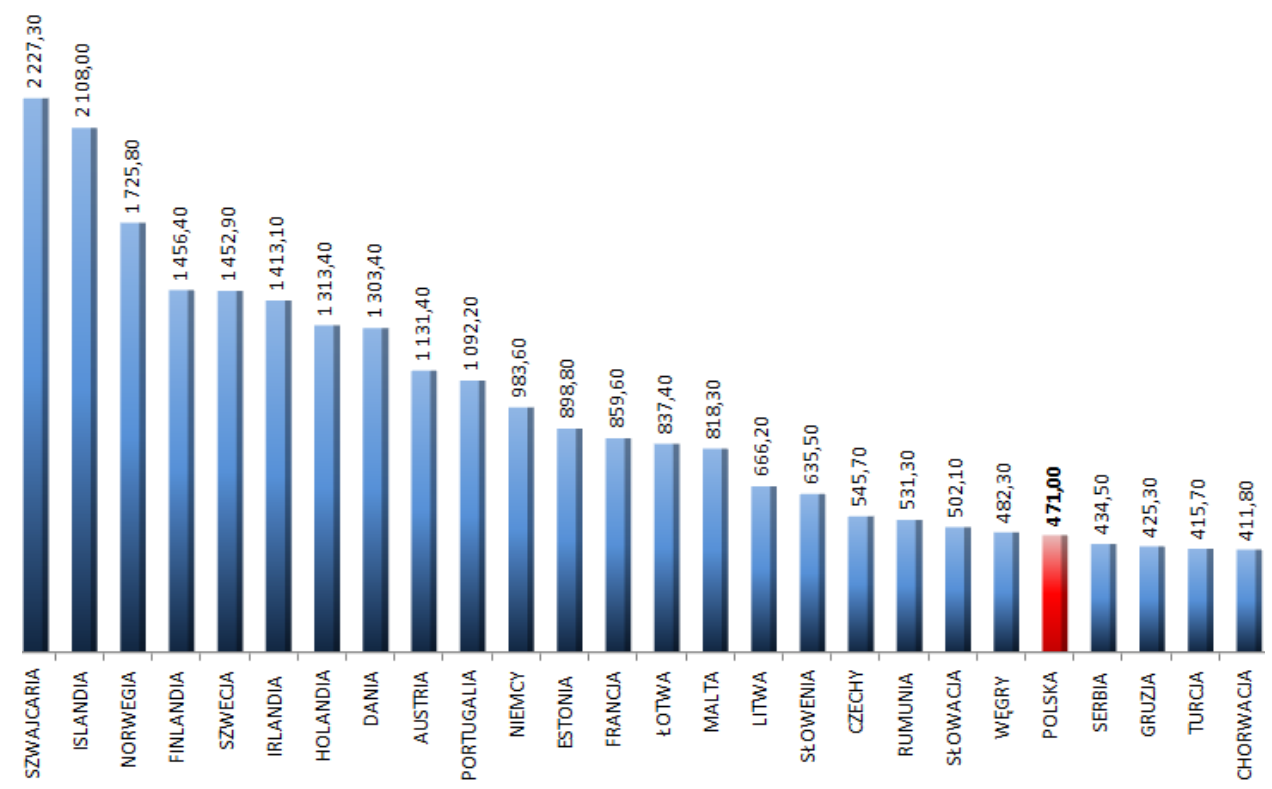

Wykres 1. Budżet studenta na miesiąc (w euro)

Źródło: upracowanie na podstawie RAPORTU ZBP Portfel Studenta Edycja III, Październik $2018 r$.

W budżet studenta wliczamy także wsparcie finansowe od rodziców. W zestawieniu 26 krajów, Polska pod tym względem jest ostatnia. Miesięczne wsparcie od rodziców wynosi 215,60 euro. Dla porównania pierwsze miejsce zajmuje Szwajcaria. Tam student dostaje 1 010,60 euro. Na kolejnych miejscach plasuje się Irlandia (812,10 euro), Portugalia (777,60 euro) oraz Islandia (732,90 euro). W tych państwach rodzice $\mathrm{w}$ największym stopniu wspierają pieniężnie swoje dzieci [RAPORT ZBP Portfel Studenta Edycja III, Październik 2018 r.].

$\mathrm{Z}$ drugiej strony polski student dzięki niskiemu wsparciu finansowemu od rodziców, musi szybciej się usamodzielnić. Na pierwszym miejscu plasuje się Estonia i Austria, tam aż 57\% miesięcznego budżetu stanowią środki własne, 
a w Rumunii i w Polsce 54\%. Najmniej, bo tylko $15 \%$ pieniędzy z własnego wynagrodzenia posiadają serbscy studenci, co za tym idzie nie spełniają się zawodowo (wykres 2).

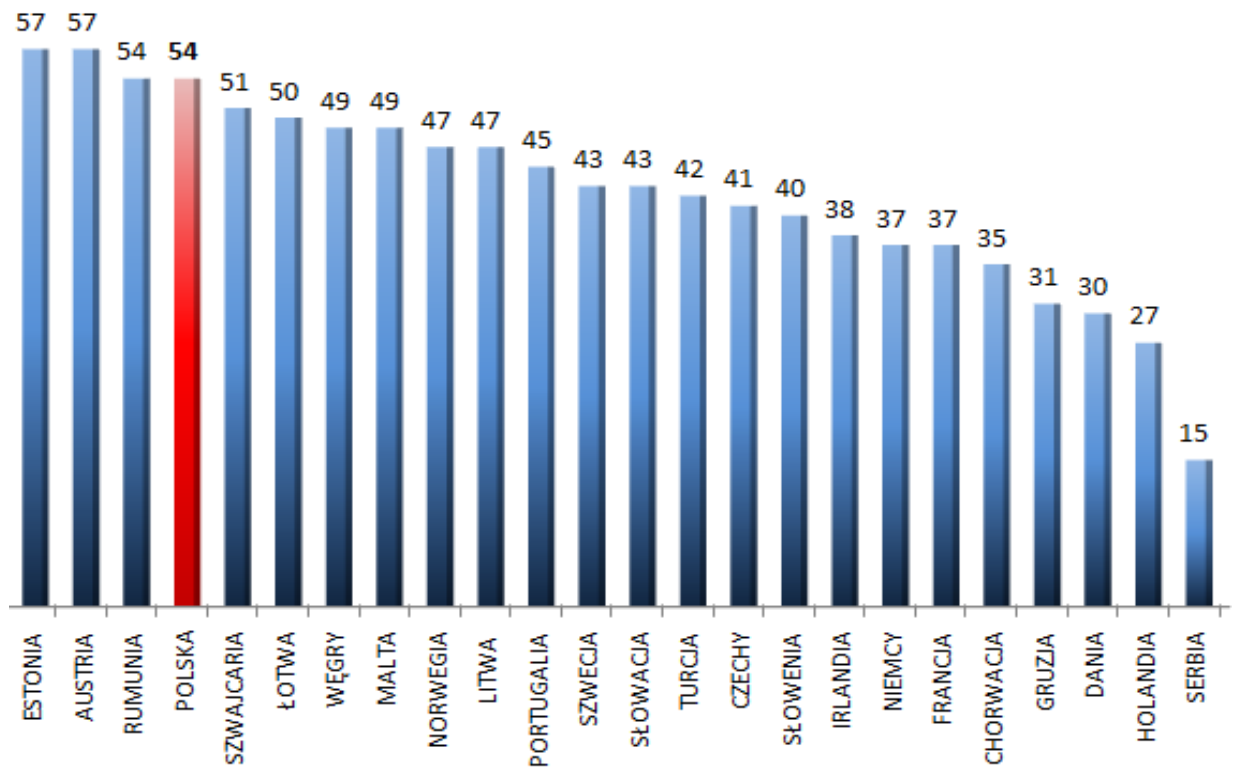

Wykres 2. Własne wynagrodzenie studentów w miesięcznym budżecie (w \%)

Źródło: opracowanie na podstawie RAPORTU ZBP Portfel Studenta Edycja III, Październik $2018 r$.

Studiowanie łączy się także z usamodzielnieniem. Część studentów wyprowadza się z domu rodzinnego, a część zostaje. 96\% studentów z Finlandii wyprowadza się od rodziców idąc na studia, a jedynie $4 \%$ zostaje. Pozostałe kraje skandynawskie utrzymują podobny poziom. Studenci w Danii (8\%), Norwegii $(9 \%)$ oraz Szwecji (13\%) nie mieszkają ze swoimi rodzicami. Z drugiej strony są studenci z Malty (73\%), Włoch (69\%) oraz Gruzji (66\%). W tych trzech państwach bardzo duża liczba studentów pozostaje w swoim domu rodzinnym. Sytuacja ta może być spowodowana długim czasem edukacji. Także jedną z przyczyn mogą być kwestie finansowe, a mieszkanie z rodzicami jest korzystniejsze niż zakwaterowanie na stancji. Na taką sytuację składa się m.in. niestabilna praca bądź jej brak. Jednak są przypadki, że dla studentów mieszkanie z rodzicami jest po prostu wygodniejsze. W Polsce większość młodych, bo aż $60 \%$ po ukończeniu szkoły ponadgimnazjalnej wyprowadza się z domu ro- 
dzinnego, stawia na samodzielność i niezależność [RAPORT ZBP Portfel Studenta Edycja III, Październik 2018 r.; Rek-Woźniak 2016: 91].

Zaczynając studiowanie trzeba brać pod uwagę wyprowadzkę z domu rodzinnego. Część osób nie musi zmieniać miejsca zamieszkania, jednak większość osób studiuje daleko od domu. Wynajmowanie mieszkania jest bardzo kosztowne i zabiera największą część budżetu studenta. Student idący na studia do nowego miasta, jest zmuszony zapewnić sobie zakwaterowanie. Nieduża część osób wynajmuje samemu mieszkanie, jednak większości musi wystarczyć własny pokój, wynajmując go w mieszkaniu z innymi osobami, znajomymi, bądź zupełnie obcymi ludźmi. Część z nich stara się o pokój w akademiku. Jak wynika z wykresu 3,78,9\% polskich studentów wydaje na zakwaterowanie mniej niż 1000 zł miesięcznie, a 98,2\% studentów płaci więcej niż $250 \mathrm{zł}$. Najwięcej (35\%) studentów płaci za wynajem 250-500 zł, nieco mniej $(27,2 \%)$ wydaje 500-750 zł.

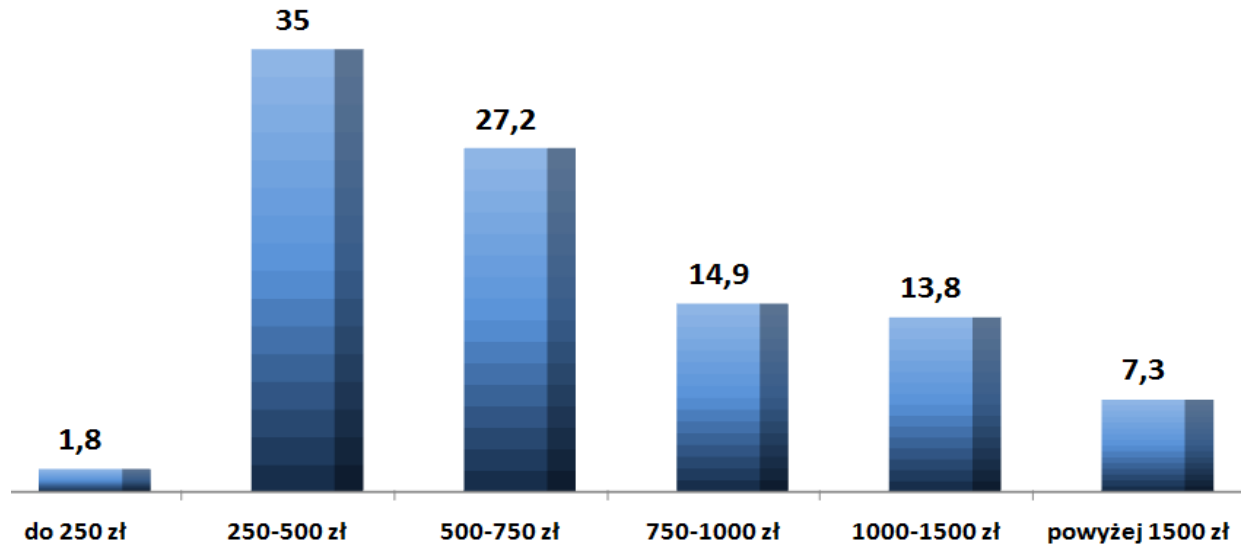

Wykres 3. Miesięczne koszty za zakwaterowanie polskich studentów $2018 r$

Źródło: opracowanie na podstawie RAPORTU ZBP Portfel Studenta Edycja III, Październik

\section{CHARAKTERYSTYKA KREDYTU STUDENCKIEGO}

Młode osoby, które po maturze podejmują decyzje o dalszej edukacji, nawet mimo wyboru bezpłatnej uczelni ponoszą duże koszty [Mirowska-Loskot, dostęp: 28.09.2016]. Związane są one z opłatami za mieszkanie bądź akademik, za żywność, kosmetyki, książki, komunikację miejską, a także opłaty związane z wydatkami na różnego rodzaju rozrywki [Sadowski, dostęp 14.03.2019]. Stu- 
denci należą do grupy osób bardzo ambitnych, chcących się rozwijać i zdobywać doświadczenie, dlatego chcą zacząć pracować, lecz nie każdy student jest $\mathrm{w}$ stanie pogodzić pracę i studia, z powodu nadmiaru nauki oraz studiowania na wymagających kierunkach [www16]. Część osób jest wspierana finansowo przez swoich bliskich, ale i w tym przypadku nie każdy ma taką możliwość. Alternatywą dla takich osób jest kredyt studencki. Można go nazwać także substytutem transferów międzypokoleniowych w rodzinie, czyli pomocy finansowej ze strony rodziców lub dziadków.

System funkcjonowania kredytów studenckich jest powszechny na całym świecie. W szczególności są wykorzystywane jako źródło finansowania edukacji. Pierwsze systemy zostały wprowadzone w latach 50. i 60. XX wieku w Europie, Ameryce Łacińskiej, a także w USA, zaś nowsze systemy zostały wprowadzone w 70. i 80. latach. Jednak w każdym z krajów systemy te nieco się różnią się [Woodhall 1987: 1].

W Stanach Zjednoczonych wprowadzenie kredytów studenckich miało ogromne znaczenie w ewolucji polityki szkolnictwa wyższego. „Zwiększenie dostępności szkolnictwa wyższego, rosnąca liczba studentów i kandydatów spoza tradycyjnych grup społecznych czy etnicznych wraz z narastającym napięciem okresu zimnej wojny zmusiły prezydenta Harry'ego Trumana do zbadania znaczenia i roli szkolnictwa wyższego dla rozwoju i bezpieczeństwa Stanów Zjednoczonych" [Rybkowski 2018: 102]. Zaproponowano, by publiczne uczelnie były darmowe. Rozwiązanie to nie zostało jednak przyjęte, co przyczyniło się do kryzysu zadłużenia absolwentów. Próbowano rozwiązać problem, który wynikał z płatnych studiów na uczelniach prywatnych, jak i publicznych. Ustanowiono nową ustawę Higher Edcuation Act of 1965, która była częścią programu „Wielkiego Społeczeństwa” prezydenta Lyndona B. Johnsona. Dzięki niej stworzono system, który zapewniał studentom wsparcie finansowe w postaci bezzwrotnych pożyczek oraz kredytów gwarantowanych. Początkowo udzielanie kredytów studenckich działało jak należy i nie stanowiło żadnego zagrożenia. Jednak „, początkiem XXI wieku ujawnił się niepokojący trend, który podważał sensowność indywidualnej inwestycji w szkolnictwo wyższe, zwłaszcza finansowanej za pomocą kredytu studenckiego. Przy uwzględnieniu inflacji mediana rocznych zarobków absolwentów typowych czteroletnich studiów undergraduate zaczęła się wyraźnie zmniejszać" [Rybkowski 2018: 103]. Bardzo szybko wzrastało zadłużenie absolwentów w USA. W 2005 roku zadłużenie wynosiło 391,1 mld USD, nakłady 398,9 mld USD. Dla porównania w 2015 roku sytuacja się odwróciła: zadłużenie wyniosło 1230,7 mld USD, zaś nakłady 581,9 mld USD. Niepokojąca także stała się coraz większa liczba starszych ludzi, którzy jeszcze kredytu studenckiego nie spłacili i być może nie uda im się już go spłacić [Rybkowski 2018: 102-106]. 
W Polsce kredyty studenckie pojawiły się w późniejszym czasie niż w Stanach Zjednoczonych. W nr 12 pisma Nauka i Szkolnictwo Wyższe w roku 1998 został przedstawiony wywiad z prof. dr hab. Jerzym Zdradą, który w tamtym czasie był podsekretarzem stanu w Ministerstwie Edukacji Narodowej. Wywiad został przeprowadzony na temat pożyczek i kredytów studenckich. Program pomocy studentom został wprowadzony w Polsce w 1998 r., zaś prace nad tym systemem zaczęly się nawet kilka lat wcześniej. Na początku środowisko studenckie miało wątpliwości, co do takiej formy pomocy udzielanej przez państwo. Jednak z czasem obawy mijały i w listopadzie 1997 roku, ostatecznie poparło wprowadzenie kredytów studenckich [Dąbrowa-Szefler 1998: 71-72]. Jak tłumaczy prof. dr hab. Jerzy Zdrada, w jego przeświadczeniu ,jest to jeden z najistotniejszych obowiązków konstytucyjnych państwa oraz bardzo ważne uprawnienie obywatelskie" [Dąbrowa-Szefler 1998: 71-72].

W ciągu pierwszych czterech lat funkcjonowania systemu udzielania kredytów studenckich kredyt otrzymało 174,5 tysięcy osób. Można zaobserwować, że kredyt był bardziej popularny na początku, lecz z roku na rok coraz mniej. W roku akademickim 1999/2000 wniosek złożyło 58700 studentów, natomiast w roku 2001/2002 jedynie 30 437, w tym kredyt otrzymało tylko 26500 osób.

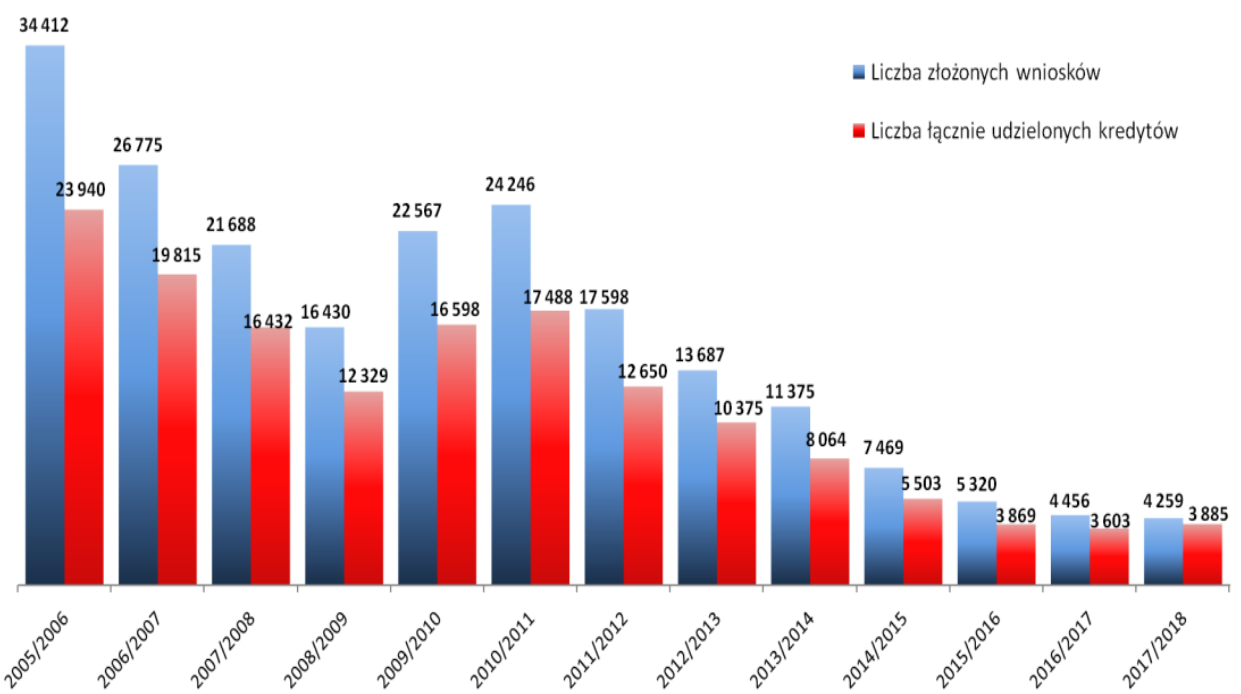

Wykres 4. Zestawienie liczby złożonych wniosków a liczba udzielonych kredytów studenckich w latach 2005-2018

Źródło: opracowanie na podstawie danych udostępnionych przez MNiSW [z:] Informacja w sprawie liczby udzielonych kredytów studenckich w roku akademickim 2005/2006, 2006/2007, 2007/2008, 2008/2009, 2009/2010, 2010/2011 2011/2012, 2012/2013, 2013/2014, 2014/2015, 2015/2016, 2016/2017 według stanu na dzień 31 marca (każdego z tych lat). 
Według Małgorzaty Dąbrowy-Szefler ,sytuacja ta wynika z faktu, że - podobnie jak całość wydatków budżetowych na szkolnictwo wyższe - wzrost dotacji na pomoc materialną dla studentów był nieadekwatny do wzrostu ogólnej liczby studentów, także do wzrostu liczby studentów w uczelniach państwowych" [Dąbrowa-Szefler 2002: 135]. W kolejnych latach, jak zostało to przedstawione na wykresie 4, liczba złożonych wniosków nie jest utrzymana na równym poziomie. W roku akademickim 2017/2018 zostało złożonych już tylko 4259 wniosków.

Liczba złożonych wniosków nie jest równoznaczna liczbie udzielonych kredytów studenckich. Sytuacja ta jest spowodowana tym, że nie każdy student spełnia wymagania związane z udzieleniem takiego kredytu. Część z osób składających wniosek nie stawiła się do banku w celu sfinalizowania umowy lub „nie podpisała jej z takich powodów, jak np. nagła poprawa sytuacji materialnej, podjęcie pracy, rezygnacja ze studiów, niesolidność przy spłacaniu innych kredytów" [www2]. Ponadto grupa osób nie uzyskała kredytu z powodu nieodpowiedniego zabezpieczenia tego kredytu [www2].

\subsection{Informacje o kredycie studenckim - stan na 2019 rok}

Od 1 stycznia 2019 roku Rozporządzenie Ministra Nauki i Szkolnictwa Wyższego z dnia 20 grudnia 2018 r. w sprawie kredytów studenckich wprowadziło nowe zasady przyznawania kredytów studenckich.

Zmiany zasad udzielania kredytów studenckich, jakie zaszły od nowego roku to przede wszystkim zmiana tego, w jakim wieku można otrzymać kredyt. Według nowych zasad można uzyskać go do 30 roku życia, a doktoranci nawet do 35 roku [www3]. Ubiegać się o kredyt może także osoba, która dopiero rekrutuje się na studia [www4]. Zmianie uległ także czas, w jakim świadczenie będzie wypłacane. W poprzednich latach było to 6 lat, obecnie jest 7 [www3].

Student ma możliwość podjęcia decyzji, na jakim poziomie chce otrzymywać miesięczne wypłaty. Zaznacza na wniosku czy chce 400, 600, 800 czy 1000 zł. Transze są wypłacane przez cały rok akademicki, czyli 10 miesięcy. Kredytobiorca nie otrzymuje wypłat w wakacje. W czasie, w którym student już otrzymuje kredyt, jest możliwość zmiany wysokości wypłat [www4]. W roku akademickim 2017/2018 prawie połowa kredytobiorców wybrała najwyższą miesięczną transzę, $800 \mathrm{zl}-21 \%$ studentów, transze w wysokości $600 \mathrm{zl}-29 \%$ osób, natomiast najmniejszą z transz wybrało tylko 2\% kredytobiorców [www5].

Warunkiem uzyskania kredytu jest konieczność znalezienia poręczyciela. W większości przypadków są to rodzice oraz bliscy. W razie sytuacji, w której nie są oni w stanie zabezpieczyć zwrot kredytu, Bank Gospodarstwa Krajowego 
(BGK) lub Agencja Restrukturyzacji i Modernizacji Rolnictwa może zostać poręczycielem (ARiMR) [www4].

W poprzednich latach termin składania wniosków o kredyt studencki był ściśle określony. Od początku roku 2019 zasady się zmieniły i wnioskować można w dowolnym czasie [www6]. Po wprowadzeniu nowych zasad umożliwiono wnioskodawcom składać wnioski także drogą elektroniczną, a nie tak jak było dotychczas tylko w wersji papierowej [www7].

Dotychczas zasady wyliczania dochodu na każdą osobę w rodzinie w przypadku kredytu studenckiego oraz stypendium socjalnego były różne. Wraz z nowym rozporządzeniem zasady się zmieniły i w obu przypadkach dochód będzie tak samo obliczany. Takie rozwiązanie jest ułatwieniem dla osób starających się o kredyt i stypendium, jak i dla osób, które zajmują się ich udzielaniem. Co więcej przyspieszy to także procedury z tym związane [www8].

Przez cały okres wypłaty, a także przez kolejne 2 lata po ukończeniu edukacji to państwo pokrywa odsetki od kredytu. Po tym czasie student jest zobowiązany spłacać kredyt. W tym momencie zaczynają być naliczane odsetki [www6]. Oprocentowanie tego kredytu jest dosyć niskie, w skali roku wynosi $0,875 \%$ [www9]. Ponadto kredytobiorca jest także zobowiązany zapłacić prowizję, której wysokość zależy od tego, w którym banku zaciągnięto kredyt. Procent waha się od 0 do 5\% wysokości wypłacanych transz [www10].

Nasuwa się pytanie: Co się dzieje jeśli kredytobiorca przerwie studia? W takim przypadku student zaczyna spłatę miesiąc po tym, kiedy miał obowiązek okazać w banku dokument (legitymację studencką), który potwierdza, że student nadal studiuje. Od tego momentu odsetki zostają naliczane. Wysokość tych odsetek wynosi 1,31\%. Inaczej niż w przypadku spłacania kredytu 2 lata po studiach. Po zakończeniu nauki odsetki, jakie zostają naliczane wynoszą 50\% stopy redyskontowej NBP, zaś w przypadku przerwania edukacji sytuacja się zmienia. W tym przypadku odsetki wynoszą 75\% stopy redyskontowej NBP. Jeśli student powtarza rok, bądź wziął warunek nadal otrzymuje kredyt. Bank wypłaca studentowi transze dopóki kredytobiorca studiuje, nieważne jak. Student o wszelkich zmianach dotyczących studiowania jest zobowiązany informować niezwłocznie bank [www11].

Kredytobiorca podczas okresu, w którym otrzymuje comiesięczne transze musi pamiętać, aby poinformować bank o wszystkich zmianach w planie swoich studiów. Jeśli student przerwie studia lub weźmie urlop dziekański musi niezwłocznie zgłosić to do banku, w którym zaciągnął kredyt. W takim przypadku wypłata transz zostanie zawieszona. Najważniejsze jest, by kredytobiorca cały czas posiadał status studenta. Ważne jest także, aby student pamiętał, by w terminie doręczać do banku podstemplowaną legitymację studencką. Powinien dostarczyć ją po zakończonym semestrze. W semestrze zimowym termin jest do 31 marca, zaś w semestrze letnim do 31 października. Student, który w terminie 
nie przyniesie do banku ważnej legitymacji studenckiej, nie otrzyma wypłaty transzy. Co ważne, nie ma opcji wyrównania tej transzy [www12]. W przypad$\mathrm{ku}$, kiedy to student wyjedzie za granicę studiować, musi okazać zaświadczenie, które poświadczy studiowanie poza granicami Polski [www13].

Jeśli student znajdzie się w gronie $1 \%$ najlepszych studentów, jego dług może zostać umorzony nawet o połowę. 35\% kredytu zostanie umorzone, jeśli student znajdzie się w 5\% najlepszych, zaś gdy kredytobiorca będzie w gronie $10 \%$ najlepszych studentów umorzone zostanie $20 \%$ jego kredytu. Student ma możliwość starania się o umorzenie całości, bądź części kredytu, nawet jeśli nie znajdzie się $\mathrm{w}$ gronie osób z najlepszymi wynikami w nauce [www4]. Jeśli nie jest w stanie spłacać swojego zadłużenia z przyczyn od niego niezależnych, może starać się o zmniejszenie wysokości miesięcznej raty, ma także możliwość starania się o zawieszenie spłaty. Spłata kredytu może być umorzona w całości, jeśli student poniesie uszczerbek na zdrowiu podczas wypadku bądź ciężko zachoruje [www13]. Aby uzyskać umorzenie kredytu wystarczy by studenci z najlepszymi wynikami w nauce złożyli wnioski do banku, w którym zaciągnęli kredyt z dołączonymi do niego wszystkimi niezbędnymi dokumentami, zaś osoby, które starają się o umorzenie kredytu studenckiego z innych przyczyn muszą wysłać wniosek listownie do Ministerstwa Nauki i Szkolnictwa Wyższego [www14]. Jeśli kredytobiorca podejmie decyzję by spłacić kredyt przed wyznaczonym terminem ma taką możliwość. Konieczne jest złożenie wniosku w tej sprawie [www12].

W 2017 roku 361 kredytobiorców skorzystało z możliwości umorzenia kredytu w całości bądź częściowo. Od początku udzielania kredytów studenckich, czyli od 1998 roku do 2017 roku z przywileju umorzenia skorzystało około 18,7 tys. kredytobiorców. Większość stanowiły umorzenia osób, które znalazły się w gronie najlepszych absolwentów [www10].

\section{FINANSE STUDENTÓW A DECYZJA O ZACIĄGNIĘCIU KREDYTU STUDENCKIEGO W WOJEWÓDZTWIE ŁÓDZKIM NA PODSTAWIE BADAŃ WŁASNYCH}

Celem badania jest pozyskanie informacji na temat finansów studentów, wsparcia pieniężnego od rodziców, własnego wynagrodzenia studentów, a także na temat wydatków, jakie ponoszą. Autorka pracy skupiła się także na poznaniu opinii studentów o zaciągnięciu kredytu studenckiego. Przedmiotem badań w ankiecie jest wpływ sytuacji finansowej studentów na spadek liczby udzielanych kredytów studenckich w Polsce. Autorka skupiła się na zebraniu informacji, które odpowiedzą na pytanie, dlaczego kredyt ten nie jest popularny w Polsce i czy duży wpływ na to ma sytuacja finansowa studentów.

Badanie zostało przeprowadzone na grupie 180 respondentów w wieku od 19 do 35 roku życia. Kwestionariusz ankietowy składał się z dwóch etapów oraz 
metryczki. Pierwszy etap zawierał pytania dla wszystkich respondentów takie same, związane z finansami studentów, z ich budżetem, miesięcznym wsparciem rodziców, związane z zakwaterowaniem i jego kosztami oraz z czynnikami wyboru miejsca zamieszkania. Drugi etap dzieli pytania na dwie grupy, dla osób które zaciągnęły kredyt studencki i oddzielne pytania dla osób, które tego kredytu nie zaciągnęły.

W ankiecie utworzone zostały pytania odnośnie miesięcznego budżetu, wsparcia finansowego rodziców oraz własnego wynagrodzenia respondentów. To właśnie sytuacja finansowa respondentów ma duży wpływ na jakość ich życia oraz na ich przyszłe decyzje.

Analizując odpowiedzi na temat miesięcznego budżetu respondentów można zauważyć, że najwięcej osób posiada miesięczny budżet powyżej 1400 zł, dokładnie 58 osób, co stanowi 32,2\% wszystkich ankietowanych. Natomiast poniżej 600 zł na miesiąc posiadają 33 osoby $(18,3 \%)$. Reszta odpowiedzi rozłożyła się dosyć proporcjonalnie i każda odpowiedź jest na podobnym poziomie.

Tabela 1. Tabela krzyżowa: wiek * miesięczne finansowe wsparcie od rodziców

\begin{tabular}{|c|c|c|c|c|c|c|c|}
\hline \multirow{2}{*}{ Wyszczególnienie } & \multicolumn{6}{|c|}{ Miesięczne finansowe wsparcie od rodziców } \\
\cline { 3 - 8 } \multicolumn{2}{|c|}{} & 0 & $1-400$ & $401-800$ & $801-1200$ & $\begin{array}{c}\text { powyżej } \\
1200\end{array}$ & ogółem \\
\hline \multirow{3}{*}{ Wiek } & $19-23$ & 31 & 64 & 32 & 21 & 9 & 157 \\
\cline { 2 - 8 } & $23-27$ & 12 & 1 & 2 & 5 & 0 & 20 \\
\cline { 2 - 8 } & $27-31$ & 1 & 1 & 0 & 0 & 0 & 2 \\
\cline { 2 - 8 } & $31-35$ & 1 & 0 & 0 & 0 & 0 & 1 \\
\hline \multicolumn{2}{|c|}{ Ogółem } & 45 & 66 & 34 & 26 & 9 & 180 \\
\hline
\end{tabular}

Źródło: badanie własne.

Respondenci zostali zapytani o miesięczne wsparcie, jakie otrzymują od rodziców. Okazuje się, że polscy studenci nie są w dużym stopniu uzależnieni od finansów rodziców. W przedziale wiekowym od 19-23 lat, 31 osób (ok. 20\%) nie otrzymuje wsparcia finansowego od rodziców, zaś 126 osób (ok. 80\%) miesięcznie dostaje od nich pieniądze. Jednakże aż 64 osoby (ok. 40\%) dostaje wsparcie nie większe niż 400 zł na miesiąc. Dodając do siebie liczbę osób nie dostających pieniędzy od swoich rodziców i liczbę osób dostających nie więcej niż 400 zł, wychodzi 95 osób, co stanowi ok. 60\% wszystkich osób znajdujących się w tym przedziale wiekowym. Pozostali, czyli 32 osoby dostają od rodziców od 401 do 800 zł oraz 21 osób dostaje od 801 do 1200 zł. Powyżej 1200 zł na miesiąc dostaje zaledwie 9 osób w tym przedziale wiekowym. W kolejnym przedziale wiekowym od 23 do 27 lat znalazło się 20 ankietowanych. W tym przypadku $60 \%$ (12 osób) ankietowanych w tym wieku samodzielnie się utrzy- 
muje, natomiast 40\% (8 osób) dostaje wsparcie pieniężne od rodziców, jednak nie wyższe niż 1200 zł na miesiąc. W ankiecie wzięły udział tylko trzy osoby mające więcej niż 27 lat i znalazły się w kolejnych dwóch przedziałach wiekowych, dwie z nich nie otrzymują wsparcia od rodziców, jedna zaś dostaje, ale nie więcej niż $400 \mathrm{zl}$.

Pytanie o wysokość miesięcznego wynagrodzenia własnego było wielokrotnego wyboru, dlatego respondenci mogli zaznaczyć kilka opcji. 58 respondentów odpowiedziało, że nie pracuje, 81 osób odpowiedziało, że ich wynagrodzeniem jest pensja, 71 studentów korzysta ze stypendium (nie wyodrębniając stypendium socjalnego oraz naukowego).

Pojawiły się także inne odpowiedzi: korepetycje (3 osoby), renta rodzinna (5 osób), 500+ (1 osoba), oszczędności (2 osoby), praca dorywcza (2 osoby).

W kwestionariuszu zawartych jest kilka pytań, które były przeznaczone jedynie dla osób, które nie mieszkają w domu rodzinnym. Związane są z ich miejscem zamieszkania, kosztami zakwaterowania, tym czy mieszkają sami, czy ze współlokatorami.

Tabela 2. Liczba osób mieszkających na stałe w domu rodzinnym

\begin{tabular}{|c|c|c|}
\hline Wyszczególnienie & Częstość & Procent \\
\hline Nie & 123 & 68,3 \\
\hline Tak & 57 & 31,7 \\
\hline Ogółem & 180 & 100,0 \\
\hline
\end{tabular}

Źródło: badanie własne.

Na pytanie czy respondent mieszka na stałe w domu rodzinnym 123 osoby (68,3\%) odpowiedziały, że nie mieszkają, zaś 57 osób (31,7\%) nadal mieszka.

$\mathrm{Z}$ osób, które nie mieszkają już w domu rodzinnym najwięcej mieszka na stancji ze współlokatorami - dokładnie 62 osoby $(34,4 \%)$. Kolejnym pod względem popularności miejscem zamieszkania wśród badanych studentów jest akademik. Mieszka tam 40 osób (22,2\%). Samemu na stancji mieszka 7 osób $(3,9 \%)$. Natomiast 12 respondentów udzieliło ,innej odpowiedzi”. Odpowiedzi się powtarzały. W większości związane były z posiadaniem własnego mieszkania oraz mieszkania z partnerem. Dwóch respondentów nie odpowiedziało na to pytanie.

O miesięczne koszty zakwaterowania zapytano tylko tych respondentów, którzy nie mieszkają w domu rodzinnym, czyli na to pytanie odpowiedziały 123 osoby. Największy odsetek osób, dokładnie 52 osoby (28,9\%) miesięczne koszty zakwaterowania ponoszą w wysokości od 250 zł do 500 zł. Nieco mniej, 41 osób (22,8\%) płaci miesięcznie od 500 do 750 zł. Jedynie 5 osób zaznaczyło, 
że wydaje na zakwaterowanie poniżej 250 zł. Powyżej 750 zł łącznie wydaje 25 osób z ankietowanych. Wynika z tego, że 82,9\% respondentów miesięcznie na zakwaterowanie wydaje poniżej $1000 \mathrm{zł}$.

Tabela 3. Miesięczne koszty zakwaterowania

\begin{tabular}{|c|c|c|}
\hline Wyszczególnienie & Częstość & Procent \\
\hline Poniżej $250 \mathrm{zł}$ & 5 & 2,8 \\
\hline $250-500 \mathrm{zł}$ & 52 & 28,9 \\
\hline $500-750 \mathrm{zł}$ & 41 & 22,8 \\
\hline $750-1000 \mathrm{zł}$ & 14 & 7,8 \\
\hline $1000-1500 \mathrm{zł}$ & 9 & 5,0 \\
\hline Powyżej 1500 & 2 & 1,1 \\
\hline Ogółem & 123 & 68,3 \\
\hline
\end{tabular}

Źródło: badanie własne.

\subsection{Kredyt studencki}

Kolejny etap pytań w kwestionariuszu dotyczył pytań związanych z kredytem studenckim. Pytania zostały podzielone na pytania dla osób, które nie zaciągnęły kredytu i te, które taką decyzję podjęły. Na 180 osób, 174 osoby nie posiadają kredytu studenckiego, zaś kredyt posiada zaledwie 6 osób z ankietowanych.

\subsubsection{Respondenci, którzy zaciągnęli kredyt studencki}

Na stronie internetowej MNiSW można odszukać Informacje w sprawie liczby udzielonych kredytów studenckich w roku akademickim 2017/2018 wedtug stanu na dzień 31 marca 2018 r., w której ukazane są dane związane z liczbą udzielonych kredytów w danych bankach. W roku akademickim 2017/2018 najbardziej popularnym bankiem do zaciągnięcia kredytu studenckiego był PKO Bank Polski S.A. Największa część studentów wybrała właśnie ten bank, bo aż ponad $75 \%$. Następny bank, który był najczęściej wybierany to PEKAO S.A. Około $22 \%$ studentów ubiegała się o kredyt w tym banku. Zaś dwa pozostałe banki nie są aż tak popularne i ubiegających się o kredyt studentów jest niewielu (ok. 1,5\%) [www5].

Wyniki ankiety utworzonej przez autorkę pracy potwierdzają informację zawartą na stronie internetowej MNiSW. Wśród 6 osób z ankietowanych, które kredyt zaciągnęły, 4 osoby podpisały umowę kredytową z PKO Bank Polski S.A., a pozostałych 2 studentów mają kredyt w Banku PEKAO S.A. W Banku 
Polskiej Spółdzielczości S.A. oraz w Spółdzielczej Grupie Bankowej S.A. żaden $\mathrm{z}$ ankietowanych nie zaciągnął kredytu studenckiego.

Kolejne pytanie dotyczyło wystarczalności wysokości transz. Na to pytanie 5 studentów $(83,3 \%)$ odpowiedziało, że wysokość wypłat jest dla nich wystarczalna, jedynie dla jednej osoby kwota jaką otrzymuje nie jest zadawalająca.

Tabela 4. Tabela krzyżowa: miejsce zamieszkania * wystarczalność transz

\begin{tabular}{|c|c|c|c|c|}
\hline \multicolumn{2}{|c|}{ Wyszczególnienie } & \multicolumn{3}{c|}{ Czy wysokość transz jest wystarczająca? } \\
\cline { 3 - 5 } & Tak & Nie & Ogółem \\
\hline \multirow{3}{*}{$\begin{array}{c}\text { Gdzie Pan/Pani } \\
\text { mieszka? }\end{array}$} & W domu rodzinnym & 0 & 1 & 1 \\
\cline { 2 - 5 } & Na stancji samemu & 1 & 0 & 1 \\
\cline { 2 - 5 } & W akademiku & 0 & 4 & 4 \\
\cline { 2 - 5 } & Ogółem & 1 & 5 & 6 \\
\hline
\end{tabular}

Źródło: badanie własne.

Autorka pracy pozwoliła sobie na dokładniejsze przeanalizowanie ankiety, w której student zaznaczył, że wysokość transz nie jest wystarczająca. Student ten nie pracuje oraz nie mieszka już w domu rodzinnym, mieszka zaś na stancji samemu. Miesięczne finansowe wsparcie od rodziców otrzymuje w wysokości większej niż 1200 zł. Z racji tego, że wynajmuje mieszkanie sam, koszt jego miesięcznego zakwaterowania jest dosyć duży i mieści się w przedziale 1000 -1500 zł. Z tego właśnie powodu można wywnioskować, że wysokość transz może nie być dla niego wystarczająca. Dla reszty osób wypłaty są odpowiednie. Jedna $\mathrm{z}$ tych osób mieszka $\mathrm{w}$ domu rodzinnym, cztery zaś mieszkają $\mathrm{w}$ akademiku. Ci ostatni wydają miesięcznie na zakwaterowanie od 250-500 zł. Osoba mieszkająca w domu rodzinnym nie musi ponosić kosztów związanych z czynszem, a kwota jaką wydają osoby mieszkające w akademiku jest zdecydowanie mniejsza niż koszt zakwaterowania studenta mieszkającego samemu na stancji (tabela 4).

Następne pytanie brzmiało następująco: „Na jaki okres Pan/Pani zaciągnął/ęła kredyt studencki?”. Dwóch ankietowanych napisało, że kredyt otrzymali na 2 lata, dwóch ankietowanych napisało, że zaciągnęli kredyt na 5 lat, jedna osoba na 3 lata, jedna napisała „do momentu zakończenia studiów”.

Następne dwa pytania w kwestionariuszu dotyczą zadowolenia kredytobiorcy z zaciągniętego kredytu studenckiego. Z badania wynika, że nie ma takiej osoby wśród tych, które zaciągnęly kredyt, która jest niezadowolona z zaciągnięcia kredytu. Na pytanie „Czy jest Pan/Pani zadowolony/a z decyzji o wzięciu kredytu studenckiego?" cztery osoby $(66,7 \%)$ odpowiedziały, że tak, dwie zaś zaznaczyły odpowiedź „może”. 
Pytanie „Czy jest Pan/Pani zadowolony/a z decyzji o wzięciu kredytu studenckiego?" w kwestionariuszu było w postaci skali, której odpowiedzi były od 1 do 5, gdzie 1 oznaczała, że ankietowany jest bardzo niezadowolony z zaciągnięcia kredytu, a 5 oznaczało, że jest bardzo zadowolony. Trzy osoby (50\%) zaznaczyły swoje zadowolenie na poziomie 3 , dwie osoby $(33,3 \%)$ na poziomie 4 , zaś jedna osoba $(16,7 \%)$ jest bardzo zadowolona $z$ kredytu i zaznaczyła ocenę 5 .

Następne pytanie odnosiło się do oceny procedury kredytowej. To pytanie także zostało przedstawione $\mathrm{w}$ postaci skali, gdzie 1 oznaczała, że procedura kredytowa była długotrwała i skomplikowana, zaś 5 oznaczało, że była krótkotrwała i nieskomplikowana. Trzech ankietowanych zaznaczyło ocenę procedury na poziomie 3 oraz trzy osoby zaznaczyły ocenę 4 . Oznacza to, że nikt nie jest niezadowolony z przeprowadzonej procedury kredytowej, jednak też nikt nie jest bardzo zadowolony, ponieważ nikt $\mathrm{z}$ ankietowanych nie zaznaczył oceny 5 .

Na pytanie „Czy łatwo było znaleźć poręczycieli/a?” pięć osób zgodnie zaznaczyło, że łatwo, zaś jedna osoba ze znalezieniem poręczyciela miała problem. Najczęściej poręczycielami są rodzice lub rodzina, lecz są przypadki, w których trudna sytuacja finansowa bądź życiowa nie pozwala na wskazanie poręczyciela, wtedy inną opcją jest poręczenie BGK lub ARiMR. Z osób, które zaciągnęły kredyt studencki i wypełniły ankietę dwie mają za poręczycieli rodziców, trzy korzystają z poręczenia BGK, zaś jedna z poręczenia ARiMR.

Na pytanie „Czy Pana/Pani zdaniem warto zaciągnąć kredyt studencki?” kredytobiorcy odpowiedzieli jednomyślnie, że warto. Poproszeni zostali by uzasadnili swoją odpowiedź odnośnie tego, dlaczego warto. Odpowiedzi brzmiały następująco:

- ,Jeżeli ktoś potrzebuje na jakieś większe wydatki to ten kredyt się przydaje",

- „Pomaga w życiu studenckim, a jego spłata jest dopiero po dawnym zakończeniu studiów",

- „Jest tani”,

- „Pozwala on na pewną stabilizację finansową”,

- „Jest to dobra odpowiedź na zapotrzebowanie studentów na dobry nowy start".

Z odpowiedzi udzielonych przez respondentów można wywnioskować, że kredyt studencki jest idealnym rozwiązaniem w niestabilnej sytuacji finansowej. Co więcej, jeśli brakuje komuś środków pieniężnych, respondenci polecają zaciągnięcie tego kredytu.

O spłatę kredytu obawiają się trzy osoby, jedna osoba nie wie czy się obawia, a dwie osoby zdecydowanie nie przejmują się tym, czy dadzą radę kredyt studencki spłacić. Autorka pracy przeanalizowała osobno ankiety tych osób, które zaciągnęły kredyt studencki i sprawdziła czy obawa przed spłatą kredytu ma wpływ na to czy respondent pracuje czy nie. Okazuje się, że nie ma na to 
reguły i jest to sprawa indywidualna, np. osoba która pracuje i otrzymuje stypendium, ale jej wsparcie finansowe od rodziców jest niewielkie obawia się o spłatę kredytu studenckiego, zaś w innej ankiecie osoba mająca taką samą sytuację zaznaczyła, że nie ma żadnych obaw ze spłatą kredytu, tak samo jak osoba, która nie pracuje, ale jej wsparcie miesięczne od rodziców to powyżej $1200 \mathrm{zl}$.

\subsubsection{Respondenci, którzy nie posiadają kredytu studenckiego}

Drugi zestaw pytań był przeznaczony dla osób, które nie zaciągnęły kredytu studenckiego. Tych studentów było znacznie więcej, bo aż 174 na 180 ankietowanych. Osoby te także zostały zapytane o swoją sytuację finansową, wypełniając te same pytania co osoby posiadające kredyt studencki, a także wypełniali pytania z metryczki. Poza tymi informacjami zostali zapytani o to czy słyszeli o kredycie studencki, czy wiedzą jakie są warunki zaciągnięcia takiego kredytu oraz dlaczego nie zdecydowali się wziąć kredyt studencki.

Tabela 5. Tabela krzyżowa: wiedza studentów na temat kredytów studenckich

\begin{tabular}{|c|c|c|c|c|}
\hline \multicolumn{2}{|c|}{ Wyszczególnienie } & \multicolumn{3}{c|}{ Czy słyszał/a Pan/Pani o kredycie studenckim? } \\
\cline { 3 - 5 } & & Tak & Nie & Ogółem \\
\hline Czy wie Pan/Pani jakie są & Tak & 50 & 0 & 50 \\
\cline { 3 - 5 } $\begin{array}{c}\text { warunki zaciągnięcia } \\
\text { kredytu studenckiego? }\end{array}$ & Nie & 90 & 34 & 124 \\
\cline { 2 - 5 } & Ogółem & 140 & 34 & 174 \\
\hline
\end{tabular}

Źródło: badanie własne

Tabela 6. Obawa respondentów przed spłatą kredytu studenckiego

\begin{tabular}{|c|c|c|}
\hline Wyszczególnienie & Częstość & Procent \\
\hline Tak & 77 & 44,3 \\
\hline Nie & 36 & 20,7 \\
\hline Może & 61 & 35,1 \\
\hline Ogółem & 174 & 100,0 \\
\hline
\end{tabular}

Źródło: badanie własne.

Zdecydowana większość ankietowanych nie posiada kredytu studenckiego. Jak się okazuje, prawie $20 \% \mathrm{z}$ nich nawet nie słyszała, że taki kredyt istnieje. O kredycie studenckim słyszało 140 osób. Natomiast przy następnym pytaniu o to „Czy wie Pan/Pani jakie są warunki zaciągnięcia kredytu studenckiego?” 
z tych 140 osób tylko 50 osób zaznaczyło, że wie jakie są warunki, zaś 90 osób słyszało o tym kredycie, ale słyszało tylko, że po prostu taki kredyt istnieje. Jak się okazuje w Polsce są duże braki wiedzy na temat kredytów studenckich.

Ostatnie pytanie to pytanie otwarte, w którym respondenci zostali poproszeni o krótkie uzasadnienie dlaczego nie zaciągnęli kredytu studenckiego. Odpowiedzi nie brzmiały w $100 \%$ tak samo, dlatego autorka pracy pogrupowała odpowiedzi, które miały taki sam przekaz. Ogólnie rzecz biorąc najczęściej ankietowani na to pytanie odpowiadali, że nie mieli takiej potrzeby. W taki sposób odpowiedziały aż 104 osoby. Kilka osób dodało, że dzięki otrzymanemu stypendium łatwiej im się żyje i dlatego nie czują potrzeby zaciągnięcia kredytu. Reszta odpowiedzi, które się pojawiały, ale już nie w tak dużej ilości, brzmią następująco:

- „brak problemów finansowych” (23 osoby),

- „obawa przed spłatą kredytu” (13 osób),

- „nieświadomość, że taki kredyt istnieje” (11 osób),

- „niechęć posiadania zobowiązań” (9 osób),

- „posiadanie stałej i dobrze płatnej pracy” (8 osób),

- „finansowe wsparcie rodziców” (5 osób),

- „nieposiadanie zdolności kredytowej” (5 osób),

- „brak wiedzy na temat kredytu studenckiego” (2 osoby),

- „nie zastanawianie się nad takim rozwiązaniem” (2 osoby).

Pojawiły się także inne odpowiedzi, które są znacznie bardziej rozbudowane i szczegółowe, lecz ich znaczenie było takie same jak odpowiedzi wyżej. W skrócie, ankietowani nie potrzebują kredytu studenckiego.

Każdy ze studentów według własnych możliwości stara się podejmować takie decyzje, by żyło mu się jak najlepiej. $Z$ analizy ankiety wynika, że sytuacja finansowa jest dosyć kluczowym aspektem w utrzymaniu na studiach. Część respondentów cieszy się z pomocy finansowej od rodziców, część otrzymuje stypendium, które jest w stanie rozwiązać problemy finansowe, a część studentów pracuje, bądź podejmuje się dodatkowych rozwiązań, jak np. udzielanie korepetycji, bądź praca „na czarno”. Każdy z ankietowanych ma swoje powody dlaczego zaciągnął kredyt, a dlaczego nie.

Osób z kredytem było zdecydowanie mniej niż osób, które kredytu nie posiadają. Ci respondenci mają różną sytuację finansową i różne powody zaciągnięcia kredytu. Głównym czynnikiem była pewna stabilizacja finansowa po otrzymaniu kredytu. Wszyscy ci respondenci są zadowoleni z tej decyzji, choć mają jakieś obawy i wątpliwości związane ze spłatą kredytu. 


\subsection{STYPENDIUM}

Studenci, którzy mają problemy finansowe mogą złożyć wniosek o przydzielenie stypendium socjalnego. Dodatkowo mogą starać się o zwiększenie stypendium $\mathrm{z}$ tytułu zamieszkania poza domem rodzinnym. Wysokość wypłat stypendium jest różnorodna i zależy od uczelni do jakiej uczęszcza student. W przypadku najniższego dochodu wysokość stypendium może dochodzić nawet do $1000 \mathrm{zl}$, a to tyle samo ile wynosi najwyższa transza kredytu studenckiego. Analizując dane o liczbie udzielonych stypendiów w Polsce, można zauważyć od kilku lat tendencję spadkową. Jak zostało określone w publikacji Szkoły wyższe $i$ ich finanse w 2017 roku przez Główny Urząd Statystyczny, liczba udzielanych stypendiów nie maleje ze względu na mniejsze zainteresowanie, tylko przez różne zmiany wprowadzane indywidualnie na każdej uczelni oraz zależy od malejącej liczby studentów. W roku poprzednim, tzn. 2017/2018 roku około 250 tys. studentów otrzymało stypendia [www15]. Stypendium może pomagać studentom w utrzymaniu na studiach, niestety z roku na rok jest ich udzielanych coraz mniej. Stypendium zależy od dochodów na jednego członka w rodzinie. Jeśli osoba pracuje i posiada stały dochód, ma mniejsze szanse na zdobycie stypendium. W ankiecie przeprowadzonej przez autorkę pracy na 180 respondentów, 71 osób zaznaczyło, że otrzymuje stypendium. Odpowiedź nie jest do końca sprecyzowana, ponieważ nie zostało wyszczególnione ile osób dostaje stypendium socjalne, a ile osób pozostałe $\mathrm{z}$ dostępnych w Polsce. W pewnym stopniu udzielane stypendia wpływają na sytuację finansową i możliwe, że na decyzje o zaciągnięciu kredytu.

\subsection{MIESZKANIE W DOMU RODZINNYM}

Innym aspektem, który może tłumaczyć spadek zainteresowania kredytem studenckim może być fakt, że duża liczba studentów idąc na studia nie wyprowadza się z domu rodzinnego. Jak wynika z raportu Portfel Studenta Edycja III, Październik 2018 r., który został sporządzony przez Związek Banków Polskich, około $40 \%$ studentów nadal mieszka w domu rodzinnym [Raport ZBP Portfel Studenta Edycja III, Październik 2018 r.]. Natomiast w kwestionariuszu przeprowadzonym przez autorkę pracy wynik jest zbliżony do ukazanego w raporcie. $\mathrm{Z}$ ankiety wynika, że 31,7\% ankietowanych mieszka na stałe $\mathrm{w}$ domu rodzinnym. W takim przypadku studenci mogą zaoszczędzić pieniądze, które wydaliby na wynajęcie mieszkania czy akademika. Można także założyć, że mieszkając nadal $\mathrm{w}$ domu rodzinnym studenci nie muszą wydawać pieniędzy na wydatki związane z zakupem żywności. Taka sytuacja może mieć ogromny wpływ na 
sytuację studentów. Studenci mieszkający w domu rodzinnym wydają mniej na utrzymanie na studiach niż ci, którzy wyprowadzili się z domu, dlatego też mogą nie potrzebować dodatkowych pieniędzy.

\section{PODSUMOWANIE}

Kredyt studencki jest to alternatywna forma finansowania dla studentów z trudną sytuacją finansową. Wielu młodych ludzi nie bierze takiego rozwiązania pod uwagę, niektórzy jednak nie mają innego wyjścia (np. nie mogą się zatrudnić z powodu nadmiaru nauki).

W ankiecie na 180 osób ankietowanych tylko 6 osób zaciągnęło kredyt studencki. Okazuje się, że nie jest on zbytnio popularny wśród studentów w Polsce. W roku akademickim 2005/2006 roku zostało udzielonych 23940 kredytów, zaś w 2017/2018 roku zaledwie 3 885. Nasuwa się pytanie: „Dlaczego w Polsce kredyty studenckie nie są popularne?’.

Zdecydowanie wpływ na taką sytuację mają finanse studentów. Z badań własnych autorki przeprowadzonych w formie ankiety wynika, że duża część ankietowanych nie potrzebuje wsparcia finansowego, dobrze sobie radzi z pomocą rodziców, stypendium oraz własnej pracy. Pojawiły się także odpowiedzi, w których respondenci tłumaczą, że kredyt studencki to dla nich ostateczność, wolą iść do pracy niż ,iść na łatwiznę" i się zadłużać. Istnieje raport Student w pracy 2017, w którym badanie zostało wykonane na zlecenie Jobsquare i przeprowadzone na 1002 studentach. Wynik z niego, że 65\% studentów w 2017 roku ma stałą pracę, 51\% - ma umowę zlecenie lub o dzieło, a 41\% studentów ma umowę o pracę, zaś 43\% studentów podejmuje decyzje o pracy już na pierwszym roku studiów [Raport Student $w$ pracy 2017 Jobsquare]. Okazuje się, że pod względem wysokości miesięcznego finansowego wsparcia rodziców studenci w Polsce plasują się na 26 miejscu na tle studentów z Europy, zaś pod względem wysokości własnego wynagrodzenia w miesięcznym budżecie są w ścisłej czołówce i ponad 50\% ich miesięcznego budżetu to własne wynagrodzenie. Można wywnioskować, że polscy studenci mają ogromne chęci do podjęcia pracy, bez zbędnych zadłużeń, potrafią oszczędzać i mądrze gospodarować swoimi finansami. 


\section{BIBLIOGRAFIA}

Dąbrowa-Szefler M., 2002, Problemy finansowania strategii rozwoju szkolnictwa wyższego, Nauka i Szkolnictwo Wyższe, Uniwersytet im. Adama Mickiewicza w Poznaniu, nr 2(20).

Dąbrowa-Szefler M., 1998, Pożyczki i kredyty - nowa forma pomocy państwa dla studentów. Wywiad z prof. dr hab. Jerzym Zdrada, podsekretarzem stanu w Ministerstwie Edukacji Narodowej, [w:] M. Dąbrowa-Szefler, J. Jabłecka, M. Wójcicka (red.), Nauka i Szkolnictwo Wyższe. Centrum Badań Polityki i Szkolnictwa Wyższego, Uniwersytet im. Adama Mickiewicza w Poznaniu, nr 12.

Maciejewski G., 2014, Młodzi-dorośli na rynku uslug finansowych, [w:] Handel wewnętrzny, Uniwersytet Ekonomiczny w Katowicach, nr 4.

Mirowska-Łoskot U., Wszystko co musisz wiedzieć o kredycie studenckim, [w:] https://serwisy.gazetaprawna.pl/edukacja/artykuly/979448,kredyt-studencki-jak-uzyskacsplata.html [dostęp 28.09.2016].

Raport Student w pracy 2017 Jobsquare.

RAPORT ZBP Portfel Studenta Edycja III, Październik 2018 r.

Rek-Woźniak M., 2016, Młodzi dorośli, Wzory ruchliwości społecznej w okresie transformacji systemowe, Wydawnictwo Uniwersytetu Łódzkiego, Łódź.

Rozporządzenie Ministra Nauki i Szkolnictwa Wyższego z dnia 20 grudnia 2018 r. w sprawie kredytów studenckich, Warszawa, z dnia 29 grudnia 2018 r., poz. 2468.

Rybkowski R., 2018, Edukacyjna bańka? Zadtużenie amerykańskich studentów a wyzwania polityki wobec szkolnictwa wyższego, Nauka i Szkolnictwo Wyższe, nr 1(51).

Sadowski J., Kredyt studencki jest tani, ale spłacić go trzeba, [w:] https://alebank.pl/kredytstudencki-jest-tani-ale-spaci-go-trzeba/ [dostęp 14.03.2019].

Woodhall M., 1987, Establishing Student Loans in Developing Countries: Some Guideline, Education and training series discussion paper, The World Bank, Washington, nr EDT85.

[www1] https://serwisy.gazetaprawna.pl/edukacja/artykuly/1119006,koniec-boomu-nastudiowanie-mlodzi-polacy-wybieraja-kursy.html [dostęp 15.11.2018].

[www2] https://www.archiwum.nauka.gov.pl/szkolnictwo-wyzsze/informacja-o-kredytachstudenckich-w-roku-akademickim-2006-2007,archiwum,1.html [dostęp 1.04.2019].

[www3] https://alebank.pl/kredyt-studencki-bardziej-dostepny-od-nowego-roku/ [dostęp 13.03.19].

[www4] https://alebank.pl/kredyty-studenckie-na-nowych-zasadach-co-sie-zmienilo-w-2019-roku/ [dostęp 13.03.2019].

[www5] https://www.gov.pl/web/nauka/informacja-w-sprawie-liczby-udzielonych-kredytowstudenckich-w-roku-akademickim-20172018-wedlug-stanu-na-dzien-31-marca-2018-r [dostęp 26.03.2019].

[www6] https://alebank.pl/jak-uzyskac-kredyt-studencki-lista-bankow-przyjmujacychwnioski/?id=257631\&catid=22869 [dostęp 13.03.2019].

[www7] https://www.gov.pl/web/nauka/informacja-o-kredytach-studenckich-doktoranckich [dostęp 13.03.2019].

[www8] https://konstytucjadlanauki.gov.pl/rozporzadzenie-prostudenckie-czyli-wszystko-onowych-kredytach [dostęp 13.03.2019].

[www9] https://alebank.pl/kredyt-studencki-jak-ubiegac-sie-o-wsparcie/ [dostęp 26.03.2019].

[www10] https://superbiz.se.pl/wiadomosci/kredyt-studencki-2019-jakie-sa-nowe-zasadyprzyznawania-aa-Rm93-45B5-L55W.html [dostęp 14.03.2019].

[www11] http://kredytstudencki.com.pl [dostęp 17.03.2019].

[www12] https://poranny.pl/kredyt-studencki-wszystko-co-student-musi-wiedziec-wyplatyoprocentowanie-zasady/ar/13499701 [dostęp 14.03.2019]. 
[www13] https://alebank.pl/kredyt-studencki-kiedy-mozna-starac-sie-o-umorzenie-zadluzenia/ [dostęp 14.03.2019].

[www14] https://www.zadluzenia.com/jak-umorzyc-kredyt-studencki/\#Umorzenie\%20kredytu\%

20studenckiego\%20co\%20to\%20jest [dostęp 14.03.2019].

[www15] https://stat.gov.pl/obszary-tematyczne/edukacja/edukacja/szkoly-wyzsze-i-ich-finansew-2017-roku,2,14.html [dostęp 16.05.2019].

[www16] https://bierzemykredyt.pl/238-kredyt-studencki-kompendium/.

\title{
STUDENT LOAN AS A FORM OF FINANCING
}

\begin{abstract}
In Poland, student loans have been granted since 1998. As it turns out, they are not quite popular nowadays and there are fewer and fewer student loans from year to year. The question arises why this is happening and what affects it? The purpose of this article is to present and evaluate the functioning of student loans and explain the situation why several thousand of them were granted a few years ago, but much less at present (2019). The relationship between a strong financial standing and the decision to take a student loan will also be presented.
\end{abstract}

Keywords: student loans, financial situation of students. 